\title{
Seed Independence Efforts in Mojokerto District, East Java, to Support the Soybean Self-Sufficiency Program
}

\author{
Rohmad Budiono ${ }^{1, *}$ Handoko ${ }^{1}$ Gatut Wahyu Anggoro Susanto ${ }^{2}$ Kartika \\ Noerwijati ${ }^{2}$ \\ ${ }^{I}$ East Java Assessment Institute for Agriculture Technology, Malang, Indonesia \\ ${ }^{2}$ Indonesian Legumes and Tuber Crops Research Institute, Malang, Indonesia \\ "Corresponding author.email: rohbudi68@yahoo.com
}

\begin{abstract}
Soybean is an important food commodity that has very large market potential and its needs continue to increase. For the sake of achieving self-sufficiency in soybeans, one important factor is the availability of scatter seeds. Provision of appropriate soybean seeds has a strategic role as a means of supporting increased soybean production. In the field, the seed flow system in Mojokerto Regency, East Java Province, is still facing problems, namely the absence of seed channels for rainy season cultivation in dry land so that it cannot grow a sustainable "Jabalsim" system. For this reason, this activity aims to 1) produce superior soybean seeds according to farmers' preferences to meet market demand, 2) grow seed producers in soybean development areas to ensure adequate supply and distribution of quality seeds of superior varieties, and 3) as well as assist in the application of technological innovations to reduce the yield gap. The results showed that the activity of seed production in Wuwut Village, Mojoanyar Sub-District, Mojokerto District could be categorized as independent. Indicators of independence are: 1) Establishment of a seed producer on behalf of Arifin with a certificate of breeder as Extention Seed producer number 030 / UPT.PSBTPH / MJK / VII / 2019, 2) Superior Varieties of Soybean has been adopted and developed (Dega I, Devon I, Deja II) at the research location even outside the research area, 3) Availability of seeds at all times for the needs of members, and 4) the emergence of a soybean seedling business that has partnered with seed providers. To maintain the continuity of the seeds producer that have been formed, monitoring of their business developments on a regular basis was needed. In addition, in the future, it is necessary to provide access to seed programs that are assisted as one of the seed providers and provide physical infrastructure support so that the speed and volume of seed production can increase.
\end{abstract}

Keywords: independent, seeds, soybean

\section{INTRODUCTION}

Soybean is an important food commodity that has a very large market potential and its needs continue to increase. The country with the largest soybean consumption in the world is China followed by Indonesia. Soybean in Indonesia is used as a raw material for tempeh and tofu, two foods that are of great interest to the public. [1] noted that Indonesia's soybean imports during the first semester of 2020 reached 1.27 million tons or US $\$ 510.2$ million or around IDR 7.52 trillion (exchange rate IDR 14,700).
A total of 1.14 million tonnes of which came from the US.

According to [2], until 2020 soybean production is predicted to increase at a rate of $0.19 \%$ / year, while [3] reported that consumption will increase by $2.36 \%$ / year. The projection results of soybean demand per capita in 2018-2022 are estimated continue to increase, an average of $3.92 \%$ per year. A significant increase in soybean consumption occurred in 2019 amount to $7.19 \%$, from 2018 amount to 2.26 million tons to 2.42 million tons. In 2022, the national consumption of soybeans is 
estimated to be close to 3 million tons, which is 2.75 million tons [4]. [5] reported that the average import of Indonesian soybeans reaches 2 million-2.5 million tons per year. Of the total import volume, around $70 \%$ is allocated for tempeh production, $25 \%$ for tofu production, and the leftovers for other products. Meanwhile, the average demand for soybeans in Indonesia reaches 2.8 million tons per year. Indonesia actually experienced self-sufficiency in soybeans in 1992. At that time, domestic soybean production reached 1.8 million tons.

In order to achieve self-sufficiency in soybeans, one of the most important factors is the availability of high yielding varieties because it is the key to increasing production. However, the success of developing superior varieties is determined by the availability of seeds and the quality of the seeds themselves [6]. Public sector breeding activities and private sector seed companies can be effectively involved, the adoption by these farmers will support a breeding process that focuses on the variety niche, meet the demands of small farmers, so that the market will come forward and develop to absorb the yields, and the policy will be implemented. to support market development, inputs and outputs [7]. Problems in soybean seedlings, among others: a) the unsatisfactory condition of the seeds that meet the six right conditions, b) less attractive soybean seeds business, so that the number of seeds producers is limited, c) the risk is quite high because the seeds are less durable for long storage, d) good seeds storage space is not available, e) weak market guarantee (unclear demand map), f) planting area per smallholder so that the need for seeds is small, and $\mathrm{g}$ ) availability of source seeds is limited. Provision of appropriate soybean seeds has a strategic role as a means of technology to support increased soybean production $[8,9,10]$.

The production system, certification, and distribution of certified seeds is currently regulated [11]. However, the implementation in the field still occurs several problems including: a) the provision of seeds is late so that it is not suitable for the planting season, b) the number of seeds need is not fulfilled, c) the quality of the seeds is not good, d) the available varieties are not in accordance with the needs of farmers, and e) the quality of the seeds is not good. Until now, soybean self-sufficiency has not been achieved because it is faced with various obstacles in its implementation as a result of (a) low farmers' interest, (b) the underdeveloped application of recommended technology at the farm level, especially the use of superior quality seeds and the use of balanced fertilizers, (c) increase in soybean imports due to the ease of import trading with reverse LC and (d) competition for land resource use with other commodities, particularly maize [12].

The spread of new high yielding soybean seeds varieties is still an obstacle, while the requirements to become seeds producers are still classified as heavy, namely: must have adequate facilities (land, processing and storage facilities), skilled personnel, comply with regulations in seeds production and certification [13]. Therefore, it is necessary to assist farmers in accessing and obtaining good quality seeds. One of the important factors in increasing agricultural production is the use of high-quality seeds [14]. In addition, it is necessary to strengthen farmer groups or individual farmers in the area to become seeds producers, so that the continuity of the supply of seeds is guaranteed with good quantity and quality.

The Indonesian Agency for Agricultural Research and Development (IAARD) determines several policies: (1) The Seeds Independent Village Model (Model Desa Mandiri Benih) is changed to the Seeds Independent Area Model, namely a model for providing seeds to meet the needs of local seeds by empowering prospective seeds producer to become formal (certified) seeds producer, (2) Model of Independent Rice Seeds Areas in 24 Provinces, Corn in 7 Provinces, Soybean in 12 Provinces [15]. To improve the ability and capacity of farmers as seeds producer was done through the process of production, processing, organizational management and marketing through indoor and field training, therefore Field School of Seeds Independent of Soybean is needed. Seed's independence is created in the sense of fulfilling the needs of its own seeds or meeting the needs of group, village or area seeds from varieties that are in accordance with farmer preferences and location-specific adaptive. The objective of the Seed Independent Village was to facilitate farmer groups, seeds producers' groups or joint seeds producers' groups to increase capacity (capacity building) in order to produce seeds to meet the needs of seeds in their area [16].

To support these activities, Indonesian Legumes and Tuber Crops Research Institute (ILETRI) is tasked with: (1) Providing sources seeds for superior varieties, (2) Providing technical guidance on seeds production, (3) Duplicating technical guidelines for seeds production and processing, and (4) Monitoring at mentoring locations. Meanwhile, Assessment Institute of Agricuture Technology (AIAT or BPTP) has the task of: (1) Assisting in planning to meet the needs of seeds in an area, (2) Identifying non-formal 
seeds producer as candidate of seeds producer, (3) Providing technical assistance and guidance for seeds production, (4) Distributing certified seeds to seeds producers, (5) Facilitating seeds producers in the seed's certification process. The Indonesian Center for Food Crops Research and Development (ICFORD) was assigned the task of compiling a General Guidelines for the development of an independent seeds area, drafting a Ministerial Assignment letter regarding the provision of certified seeds for rice, maize, soybeans, and compiling a schedule for the implementation of activities.

The research objectives were: producing superior soybean seeds according to farmer preferences to meet market demand. In addition, growing seeds producers in soybean development areas to ensure adequate supply and distribution of high-quality superior variety seeds, as well as assistance to reduce yield gaps between farmers by improving cultivation.

\section{MATERIALS AND METHODS}

\subsection{The Scope of Research}

The scope of this activity was a model of soybean seeds independent area and its development. Activities were carried out include: 1) Identification of existing technology, 2) Planning of seed requirements, 3) Identification of prospective seeds producers and potential locations. Selected locations that have farmer groups (Poktan or Gapoktan), as well as the existence of support groups that focus on agriculture, 4) Provision of certified seeds (mapping surveys and seed needs and farmers' access to formal seedlings in the Seed Independent area), 5) Technical assistance and guidance of production seeds, 6) Facilitation and guidance of the seed certification process (in collaboration with the Agriculture services and Technical Implementation Unit for Supervision and Certification of Food Crops and Horticulture Seeds (UPT PSB-TPH), 7) Seeds information systems, and 8) Monitoring, evaluation and reporting of seeds production.

The development model of soybean seeds independent village was implemented in Mojokerto District, which was carried out from January to December 2019. The activity was carried out in a model of production field school by holding a field laboratory. The variety planted in field laboratory is the Dega I variety, which is a cross between the Grobogan and Malabar varieties [17]. The production techniques used are as recommended by ILETRI with technology and quality management assistance. It is hoped that the one-hectare area around the field laboratory can be used as a supporting area for these activities.

\subsection{Implementation}

Prospective seeds producers who are targeted to become seeds producers in the seeds independent area model are seeds producer or farmers who were usual to producing seeds but, in the production, process have not yet certified the seeds to Seed Supervision and Certification Center (BPSB). The identification process coordinates with BPSB to determine prospective non-formal seeds producers to be coached. Fostering the seeds producers included: seed production techniques (pre- and post-harvest) as well as the seed certification process, so that the informal seeds producers can develop into formal seeds producer.

The selection of prospective locations for the seeds independent area model was based on the planted area of Rice-Corn-Soybean (or Pajale), which mean that the seeds independent area model located in both the central area and the development of Pajale. The Field School - Village of Soybean Independent Seeds $(S L-D M B)$ activities were held in Wuwut Village, Mojoanyar Sub-District, Mojokerto District, in Harapan Jaya and Tani Mulyo Farmers Group.

This activity uses Foundation Seeds (FS) class from ILETRI and seeds was planted in one hectare of field laboratory as a place for farmers to learn firsthand how to produce seeds and see the appearance of the varieties being introduced. The Stock Seeds (SS) class produced can be used by prospective seeds producers to produce Extension seeds (ES) if desired. Production of ES seeds class in field laboratory will be registered with $B P S B$ by the formal seeds producers that established in the region.

\section{RESULT AND DISCUSSION}

\subsection{The characteristics of soybean $S L-D M B$ activity locations (Ex-ante).}

The results of a survey to 49 prospective implementers of Soybean $S L-D M B$ showed that the agricultural area in Wunut Village is 112 hectares, divided into two cropping systems, namely the dry season I (rice-soybeans-soybeans) covering 6 hectares and the dry season II (rice-rice-soybean) covering an area of 106 hectares. The planting system of dry season I covering an area of 6 hectares, was found in the Harapan Jaya Farmer Group of 1 hectare 
and Tani Mulyo covering an area of 5 hectares. For dry season II, it is divided into 26 hectares in Harapan Jaya Farmers Group, 34 hectares in Tani Mulyo, 20 hectares in Harapan Makmur I, and 26 hectares in Harapan Makmur II.

\subsection{Seeds Origin}

Mojoanyar sub-district has no seeds producers, especially soybeans. So far, soybean seeds are obtained from: 1) Purchasing at a kiosk that is far from the location, 2) Buying from other farmers in bulk (jabal sim), 3) Self-harvesting, and 4) Government assistance (Figure 1). The varieties grown include: Grobogan, Gepak Ijo, Wilis, Devon, and Dega. The Devon and Dega varieties were the result of the previous year's Field School activities kept by cooperator farmers of $S L-D M B$ (Figure 1B).

The problem that often occured that the seeds used are not in accordance with the six right principles, namely: 1) Right variety, not in accordance with farmers wishes, especially assisted seeds or those in agricultural kiosks, 2) Appropriate quality, low growing power, 3) Right amount, it can be ascertained that the seed assistance from the government is not sufficient, 4) Right location, the location of the agricultural kiosk is in the city, the distance is relatively far from the location. 5) On time, the availability of seeds in kiosks and accommodation seeds is not on time when needed, and 6) Right on price, farmers feel that the price of soybean seeds is still too expensive, ranging from IDR 10,000 - IDR 12,500 per kg.
A

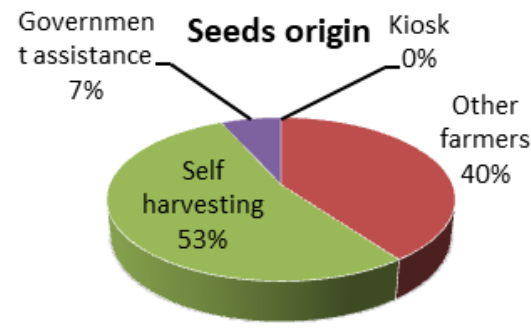

B

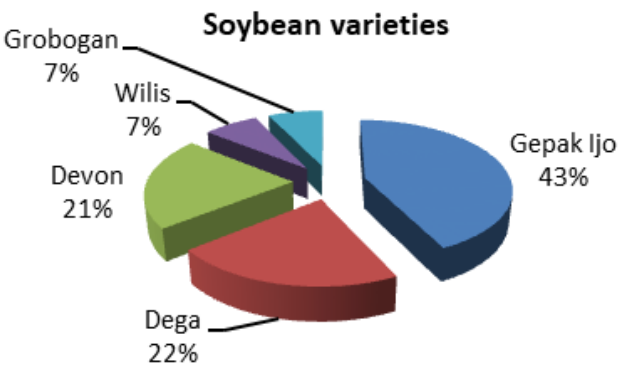

Figure 1. Diagram of: A. Origin of Seeds and B. Soybean varieties before the implementation of Soybean SL$D M B$ (Dry season I 2018).

\subsection{Soybean Planting Area}

Mojoanyar sub-district in the 2018 planting season has a soybean planting area of 277 hectares, ranking second after Bangsal District (415 hectares). In general, the area of soybean cultivation in Mojokerto Regency in 2018 has decreased significantly compared to the previous year, namely in 2017 the area of 3636.9 ha decreased to 1480 ha in 2018 (decreased 59.31\%) (Figure 2A). This is caused by the price of soybeans is low, so it switches to corn.

\subsection{Average of soybean production in 2018 (before the soybean SL-DMB was carried out)}

Soybean production during the planting season of dry season I in 2018 before the 2019 Soybean $S L-D M B$ activities very fluctuated among farmers (Figure 3). This is because farmers think soybeans are not a superior commodity because of their low selling price, so that it has an impact on less intensive cultivation methods, including: spread planting, not fertilizing, weed control and pest control are not optimal. 

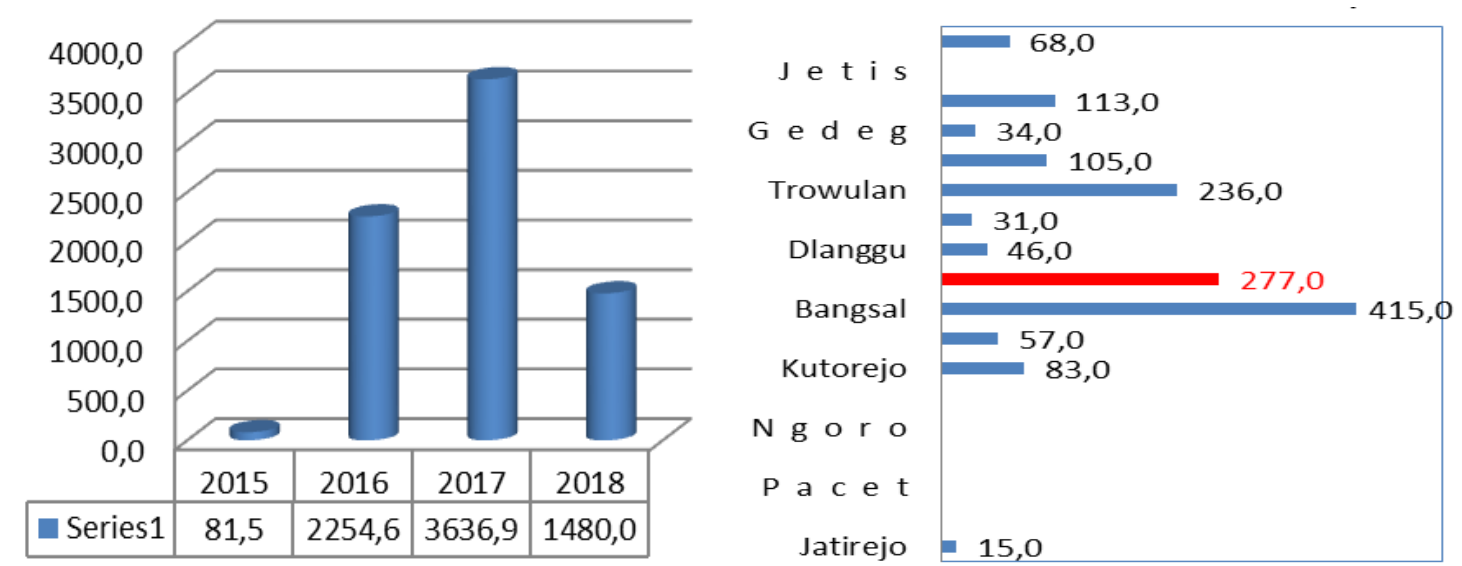

Figure 2. Soybean planting area in Mojokerto District: A. Total soybean planting area in Mojokerto district. B. Soybean planting area per subdistrict in Mojokerto

\subsection{Implementation of Soybean SL-DMB Activities in 2019}

\subsubsection{Determination of seeds producers}

Prospective seeds producers are determined based on the selection of Soybean $S L-D M B$ participants at the time of socialization and under the direct supervision of officers from the Technical Implementation Unit for Supervision and Certification of Food Crops and Horticulture Seeds. From the three names of seeds producers that submitted, one name that met the requirements to become a seeds producer was chosen, namely Arifin and finally obtained a certificate with a recommendation number as Bina Seed Producer No. 030 / UPT.BPSBTPH / MJK / VII / 2019, with the business name "Maju Jaya".

\subsubsection{Determination of Produced Seeds and Their Utilization.}

Determination of soybean varieties produced as seed candidates is based on: 1) the best of new varieties of IAARD from the demonstration plot from a few years earlier, 2) The results of group members' agreement, and 3) Partner Orders. Therefore, two new superior varieties of soybeans were selected, namely: Dega 1 and Devon 1. The Dega variety was chosen because it has advantages, namely large seeds and short life, while the

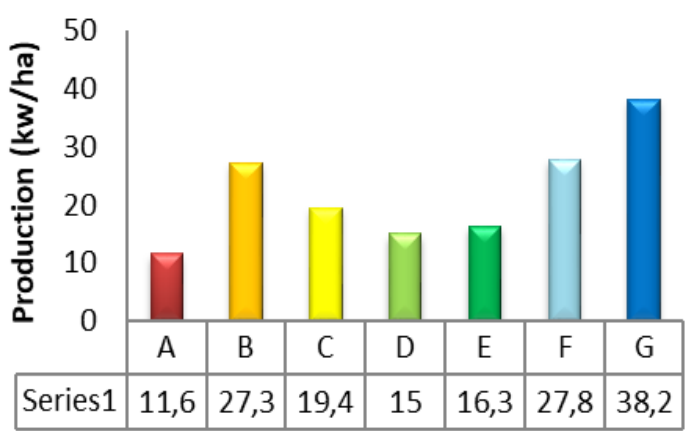

Figure 3. Soybean productivity (average yield, kw. $\mathrm{ha}^{-1}$ ) at the location of the Soybean $S L \_D M B$ activity in dry seasin I 2018 (before assistance was carried out in 2019). $A=$ lowest farmer's yield, $B=$ highest farmer's yield, $\quad C=$ farmer's average yield, $\mathrm{D}=$ provincial average yield, $\mathrm{E}=$ average yield at $\mathrm{SL}$ 2018, F=average yield of Dega 1, F=potential yield of Dega 1.

Devon I variety has higher production than local varieties. In addition, there is Deja 2 variety, a new soybean variety that has never been planted at the location of the activity and has the advantage of being water-saturated, so it is hoped that it will be suitable for planting in the soybean SL-DMB activity location in dry season I.

In the planting season of dry season, I in 2019, Soybean $S L-D M B$ activities prioritized producing seeds to meet the needs of members of the two farmer groups in the Wunut village area, namely: the Harapan Jaya and the Tani Mulyo farmer group which had the dry season II planting area $( \pm 112$ hectares), while the area of soybean in Mojoanyar sub-district in dry seaon II is \pm 266 hectares, so that the soybean seeds needed is $\pm 13,300 \mathrm{kgs}$. 


\subsubsection{The number of seeds produced and their use}

Soybean seeds produced in this activity were produced in two planting seasons, namely production in dry season I and dry season II 2019. Seed production in dry season I was prioritized for the needs of group members, while seed production in season dry season II served the needs of members, farmers outside the Wunut area and partnership with East Java AIAT (Table 2).

The problem faced by seeds producers in producing seeds / prospective soybean seeds in large quantities is the lack of facilities and infrastructure they have. Currently, they still use conventional methods in processing seed candidates. In the future, it is hoped that there will be a multipurpose tool / machine,especially to accelerate the processing of prospective seeds. The relatively short time between harvesting and planting in dry season II is also a problem in itself, so the availability of seeds must be fast. This requires readiness and speed of seed processing so that the seeds produced can be utilized optimally.
The impact of limited time and infrastructure has resulted in not all prospective seeds being produced into certified seeds, especially production during the planting season of dry season I (April-July 2019). Meanwhile, most of the production of seeds candidates in dry season II are labeled/certified, because there are not many farmers who are planting soybeans ahead of the rainy season. In addition, partnerships have been established with seed producers (Figure 4).

\subsubsection{Stakeholder involvement in technical assistance activities}

Indicators of the success of Soybean $S L-D M B$ activities are: the emergence of seeds producers in the local area, the development of new varieties, the availability of certified seeds, and the running of the seed business. To create an Independent Seed Village, technical assistance has been carried out by involving relevant agencies, namely: ILETRI, Technical Implementation Unit for Supervision and Certification of Food Crops and Horticulture Seeds (UPT PSBTPH), AIAT, Agriculture and Forestry Service of Mojokerto District.

Table 1. Need for certified seeds, as well as seed delivery realization for field laboratory and field school

\begin{tabular}{lllllll}
\hline Locations & Varieties & $\begin{array}{l}\text { Target seed } \\
\text { requirements (kg) }\end{array}$ & $\begin{array}{l}\text { Seeds } \\
\text { classes }\end{array}$ & $\begin{array}{l}\text { Realization } \\
\text { of Seed } \\
\text { Delivery (kg) }\end{array}$ & Seed Receiving Date & $\begin{array}{l}\text { Providing } \\
\text { agency for } \\
\text { seeds }\end{array}$ \\
\hline Field & Dega 1 & 50 & FS & 50 & 16 April 2019 & ILETRI \\
laboratory & Devon 1 & 50 & FS & 50 & & ILETRI \\
& Deja 2 & 50 & FS & 50 & 16 April 2019 & \\
$\begin{array}{l}\text { Field } \\
\text { school }\end{array}$ & Devon & 200 & FS & 200 & & \\
\hline
\end{tabular}

Table 2. Business activities for extension seeds in 2019

\begin{tabular}{|c|c|c|c|c|c|c|}
\hline Location & Varieties & $\begin{array}{c}\text { Production } \\
\text { plan }\end{array}$ & $\begin{array}{c}\text { Seeds } \\
\text { class }\end{array}$ & Utilization plan & $\begin{array}{l}\text { Production } \\
\text { realization }\end{array}$ & $\begin{array}{c}\text { Realization of seeds } \\
\text { utilization }\end{array}$ \\
\hline \multicolumn{7}{|c|}{ Planting season I (April - July 2019) } \\
\hline $\begin{array}{l}\text { LL: } \\
\text { Poktan Harapan Jaya }\end{array}$ & $\begin{array}{c}\text { Dega I } \\
\text { (10 farmers) }\end{array}$ & $1000 \mathrm{kgs}$ & ES & $\begin{array}{l}\text { For grup } \\
\text { member and non } \\
\text { grup member }\end{array}$ & $1.077 \mathrm{kgs}$ & $\begin{array}{c}\text { Grup member: } 577 \mathrm{kgs} \\
\text { Non grup member : } 500 \\
\mathrm{kgs}\end{array}$ \\
\hline Poktan Tani Mulyo & $\begin{array}{c}\text { Deja II } \\
\text { Devon } \\
\text { (9 farmers) }\end{array}$ & $\begin{array}{l}500 \mathrm{kgs} \\
500 \mathrm{kgs}\end{array}$ & $\mathrm{ES}$ & Grup member & $1.240 \mathrm{kgs}$ & Grup member \\
\hline $\begin{array}{l}\text { SL: } \\
\text { Poktan Tani Mulyo }\end{array}$ & $\begin{array}{c}\text { Devon } \\
\text { (30 farmers) }\end{array}$ & $5000 \mathrm{kgs}$ & ES & $\begin{array}{l}\text { For member and } \\
\text { non grup } \\
\text { member }\end{array}$ & $5.168 \mathrm{kgs}$ & $\begin{array}{l}\text { For grup member and } \\
\text { non grup member }\end{array}$ \\
\hline TOTAL & & & & & $7.485 \mathrm{kgs}$ & \\
\hline \multicolumn{7}{|c|}{ Planting season II (July -October 2019) } \\
\hline $\begin{array}{l}\text { Poktan Tani Mulyo } \\
\text { and poktan Harapan } \\
\text { Jaya }\end{array}$ & $\begin{array}{l}\text { Dega } \\
\text { Devon }\end{array}$ & $\begin{array}{l}500 \mathrm{kgs} \\
11.500 \mathrm{kgs}\end{array}$ & ES & Partnership & $\begin{array}{l}500 \mathrm{kgs} \\
10.000 \mathrm{kgs}\end{array}$ & $\begin{array}{c}\text { Partnership } \\
100 \mathrm{kgs} \\
10.000 \mathrm{kgs}\end{array}$ \\
\hline Poktan Tani Mulyo & $\begin{array}{l}\text { Devon } \\
\text { Deja }\end{array}$ & & $\mathrm{ES}$ & Grup member & $\begin{array}{l}2.000 \mathrm{kgs} \\
1.000 \mathrm{kgs}\end{array}$ & $\begin{array}{l}\text { Used for members and } \\
\text { nonmembers } \\
\text { (preparation dry season } \\
\text { I in 2020) }\end{array}$ \\
\hline TOTAL & & & & & $13.500 \mathrm{kgs}$ & \\
\hline
\end{tabular}


Implementation of assistance to farmers participating in Soybean $S L-D M B$, it is carried out in two ways, namely theory and practice in the field. The AIAT team is tasked with facilitating activities which include coordination with stakeholders and provide infrastructure. UPT PSBTPH provides assistance starting from completing the administration of submitting prospective seeds producers to obtaining certification as seeds, producers as well as providing assistance to the process of submitting seeds and monitoring/physical inspection of soybean plants in the field. ILETRI is responsible for providing source seeds and at the same time providing assistance on cultivation and harvesting methods, introduction of pests and diseases, and production methods of soybean seeds.
3.6. Improvement of Soybean Cultivation Technology

In producing soybean seeds, it is inseparable from good and efficient cultivation methods so that more potential seeds are produced, good quality, and are more cost efficient. Based on data from the previous season (dry season I in 2018), it shows that what needs to be improved is planting methods. Most of the farmers plant soybeans by spreading it, this has an impact on activities in maintenance, especially weed control, which is less than optimal so that productivity is lower than the method of planting sliced

(Figure

Table 3. Realization of Technical Assistance in Soybean Seed Production

\begin{tabular}{|c|c|c|c|}
\hline Type of mentoring & Participants & $\begin{array}{l}\text { Place of } \\
\text { activities }\end{array}$ & Interviewees \\
\hline $\begin{array}{l}\text { 1. Socialization of the program of } \\
\text { Soybean } S L-D M B 2019 \\
\text { 2. Improvement of cultivation } \\
\text { techniques }\end{array}$ & $\begin{array}{ll}- & \text { Farmer grup Tani Mulyo } \\
- & \text { Farmer grup Harapan Jaya } \\
- & \text { Agricultural extension of } \\
& \text { Mojoanyar area } \\
- & \text { Representatives of the } \\
& \text { Agriculture Services of } \\
& \text { Mojokerto }\end{array}$ & $\begin{array}{l}\text { Village meeting } \\
\text { hall of Wunut }\end{array}$ & AIAT of East Java \\
\hline $\begin{array}{l}\text { Soybean seed certification process, } \\
\text { rouging, and seed candidate } \\
\text { processing }\end{array}$ & $\begin{array}{ll}\text { - } & \text { Farmer grup Tani Mulyo } \\
\text { - } & \text { Farmer grup Harapan Jaya } \\
\text { - } & \text { Agricultural extension of } \\
& \text { Mojoanyar area }\end{array}$ & $\begin{array}{l}\text { Village meeting } \\
\text { hall of Wunut } \\
\text { continued } \\
\text { activities in the } \\
\text { field }(5 \mathrm{x})\end{array}$ & UPT-PSBTPH \\
\hline $\begin{array}{l}\text { 1. Cultivation and production } \\
\text { principles of soybean seeds } \\
\text { 2. The main pests \& diseases of } \\
\text { soybeans } \\
\text { 3. Harvest and post harvest }\end{array}$ & $\begin{array}{ll}\text { - } & \text { Farmer grup Tani Mulyo } \\
\text { - } & \text { Farmer grup Harapan Jaya } \\
\text { - } & \text { Agricultural extension of } \\
& \text { Mojoanyar area }\end{array}$ & $\begin{array}{l}\text { Village meeting } \\
\text { hall of Wunut } \\
\text { continued } \\
\text { activities in the } \\
\text { field }(3 \mathrm{x})\end{array}$ & ILETRI-Malang \\
\hline
\end{tabular}
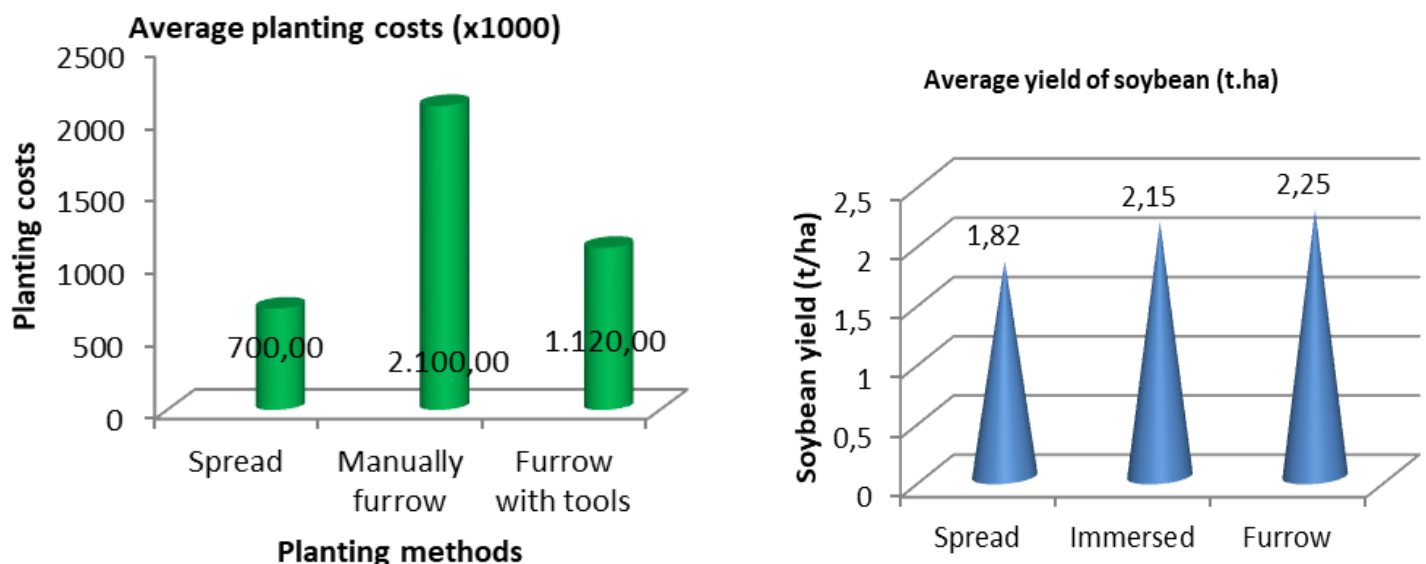

Figure 5. Comparison of wages and yields on different ways of soybeans planting. 


\subsubsection{Introduction of planting tools}

To simplify the planting of the "icir" system, a simple planting tool was introduced (Figure 6), with the aim of speeding up planting times and regular spacing as desired. This has an impact on reducing the use of labor, making plant maintenance easier so that plant growth and yield are optimal.

\subsubsection{Street light impact countermeasures}

Street lighting has a negative effect on plant growth. Soybean plants that are exposed to street lighting show the following signs: 1) the age of the plant becomes longer, for example Dega is 85 days old to 150 days old, 2) longer vegetative growth, taller plants, and 3) if the flowers do not appear have a pincer or if it is not pithy. The radius of the land affected by the lights is $25-30$ meters from the light point, this is of course very detrimental to farmers who own land along the road. To suppress vegetative growth caused by the influence of street lights, a Growth Regulator was applied which contains the active ingredient Paklobutrazol $250 \mathrm{~g} \cdot \mathrm{l}^{-1}$, sprayed with a concentration of $2 \mathrm{cc}$ per liter of water at the age of 15 DAP and 30 DAP. The results showed that soybean plants given ZPT produced $750 \mathrm{kgs} / \mathrm{ha}$ while those that were not given the pods were not fertile (did not produce seeds) (Figure 7).

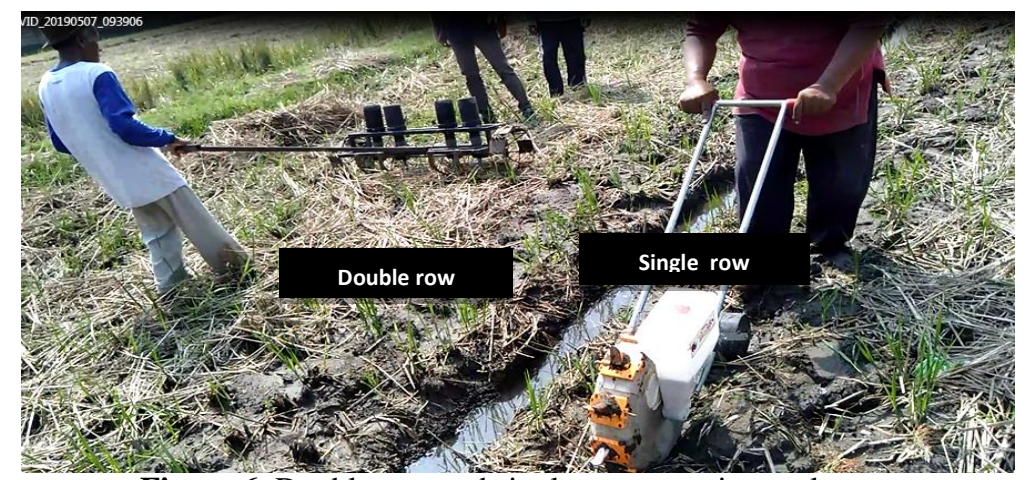

Figure 6. Double row and single row cropping tools
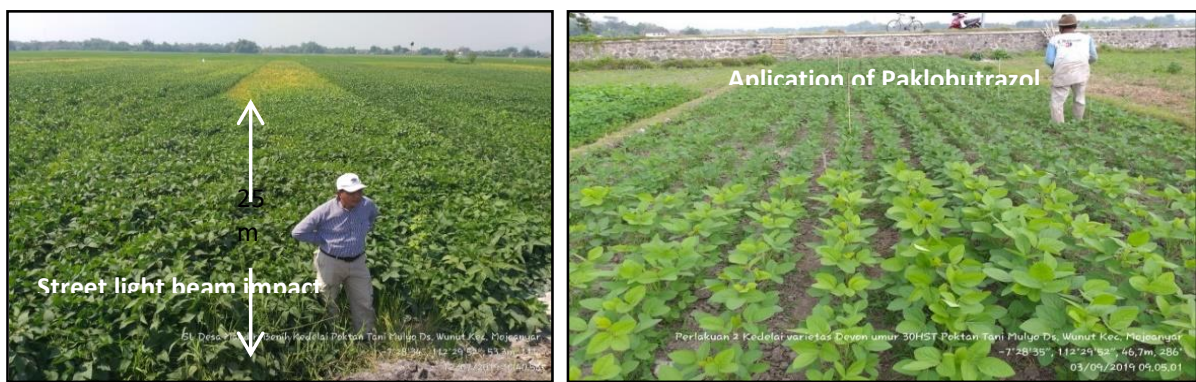

Figure 7. Plant performance affected by street lights (left) and plant performance after ZPT application (right)

For more optimal results, it is necessary to conduct a more in-depth study of the application of ZPT to plants affected by street lights, besides it is necessary for plant breeders to create soybean varieties that are tolerant of street light.

\section{CONCLUSION}

Soybean seeds production in Wuwut Village, Mojoanyar Sub-District, Mojokerto District have been independent. Indicators of independence were: 1) Establishment of a seeds producer on behalf of Arifin with a certificate as seeds producer number 030/UPT.PSBTPH/drysesason/VII/2019, 2) New soybean varieties have been adopted and developed (Dega I, Devon I, Deja II) in the location of the activities even outside the area of activities, 3)
Availability of seeds at all times for the needs of members, and 4) The emergence of soybean seeds business that has partnered with seeds providers.

To maintain the continuity of the seeds producer that have been formed, monitoring of their business developments on a regular basis was needed. In addition, in the future, it is necessary to provide access to assisted seed programs as one of the seed providers and to provide physical infrastructure support so that the speed and volume of seed production can increase.

\section{REFERENCES}

[1] Statistics Indonesia, 2020. https://www.bps.go.id/. 
[2] N. Syafa'at, et al., Projection of Demand and Supply of Main Agricultural Commodities, The Participatory Development of Agricultural Technology Project/PAATP, Bogor, Indonesia: Center for Agricultural Socio-Economic Research and Development, 2005. [In Bahasa Indonesia].

[3] M. Asaad, S.B. Sugiman, Factors Influence the Opportunity of Soybean Seed Production Technology in Southeast Sulawesi, Jurnal Pengkajian dan Pengembangan Teknologi Pertanian 3(1) (2018) 37-48. DOI: http://dx,doi.org/10.21082/jpptp.v21n1.2018.p37 -4. [In Bahasa Indonesia]

[4] D.R. Triyanti, Outlook for Agricultural Commodities Crops, Center for Agricultural Data and Information System, Secretariat General of the Ministry of Agriculture, ISSN: 1907-1507, 2020, 66p. OUTLOOKKEDELAI2020.pdf. [In Bahasa Indonesia]

[5] M. Idris, The irony of Indonesia, the country of Tempe, the majority of soybeans are imports. Kompas.com. 23/08/2020, https://money.kompas.com/read/2020/08/23/07110 0726/ironi-indonesia-negeri-tempe-kedelainyamayoritas-impor?page $=$ all. Accessed on: 3 November 2020. [In Bahasa Indonesia]

[6] Maimun, Romano, Ismayani, Strategy for provision of soybean seeds between fields and between seasons at the Aceh Food Crops Seed Center, Jurnal Bisnis Tani 3(2) (2017) 107-116. [In Bahasa Indonesia].

[7] S. Walsh, T. Remington, S. Kugbei, C.O. Ojiewo, Review of Community Seed Production Practices in Africa Part 1: Implementation Strategies and Models, In: CO Ojiewo, S Kugbei, Z Bishaw and JC Rubyogo (Eds.) Community seed production, 2015, pp.3-28

[8] D. Arsyad. Soybean seed and breeding system. Paper presented at the Soybean Seed Workhop at Indonesian Legumes and Tuber Crops Research Institute, Malang, East Java, Indonesia, 26-29 November, 2013 [In Bahasa Indonesia].

[9] Marwoto. Minister of Agriculture harvesting soybean stock 2015. http://balitkabi.litbang.pertanian.go.id/berita/mente ri-pertanian-panen-benih-pokok-kedelai/.
Accessed 4 November 2020. [in Bahasa Indonesia]

[10] G. Abebe, and Amanuel Alemu. Role of improved seeds towards improving livelihood and food security at Ethiopia, International Journal of Research - Granthaalayah 5(2) (2015) 338-356.

https://doi.org/10.29121/granthaalayah.v5.i2.201 7.1746

[11] Ministry of Agriculture. Permentan 02/2014 concerning: Production, certification, and distribution of certified seeds, 2014. PERATURAN MENTERI PERTANIAN . [In Bahasa Indonesia]

[12] A. Zakaria. Soybean Cultivation Development Policy Towards Self-sufficiency through Farmer Participation. Analisis Kebijakan Pertanian, Volume 8 No. 3, September. Center for SocioEconomic and Agricultural Policy, Bogor, 2010. DOI: http://dx.doi.org/10.21082/akp.v8n3.2010.25 9-272 . [In Bahasa Indonesia]

[13] D.O. Manzanilla, J.D. Janiya, D.E. Johnson. Establishing communitybased seed systems: a training manual. Los Baños (Philippines): International Rice Research Institute 2013, p. 215.

[14] S.G. Elias. The Importance of using high quality seeds in agriculture systems, Agri Res \& Tech: Open Access Journal 15(4) (2018). DOI: http://dx,doi.org/10.19080/ARTOAJ.2018.15.55 5961

[15] T. Sundari, Development of Independent Food Plant Seed Villages, 2014. http://balitkabi.litbang.pertanian.go.id/berita/penge mbangan-model-desa-mandiri-benih-tanamanpangan/ Accessed on: 3 January 2020. [In Bahasa Indonesia]

[16] B. Sayaka, Hermanto, M. Rachmat, V. Darwis, F.B.M. Dabukke, Suharyono, K. Karyasa. Strengthening of seed breeder institutions to support independence of rice and soybean seeds. End of year report, Center for Socio-Economic and Agricultural Policy, 2015. [In Bahasa Indonesia]

[17] ILETRI. Description of superior varieties of legumes and tubers crops, 2016. [In Bahasa Indonesia 